\title{
ARTICLES \\ Large-Amplitude Variations in Carbon Cycling and Terrestrial Weathering during the Latest Paleocene and Earliest Eocene: The Record at Mead Stream, New Zealand
}

\author{
Benjamin S. Slotnick, ${ }^{1, \star}$ Gerald R. Dickens, ${ }^{1,2}$ Micah J. Nicolo, ${ }^{1,3}$ Christopher J. Hollis, ${ }^{4}$ \\ James S. Crampton, ${ }^{4}$ James C. Zachos, ${ }^{5}$ and Appy Sluijs ${ }^{6}$ \\ 1. Department of Earth Sciences, Rice University, Houston, Texas 77005, U.S.A.; 2. Institutionen för geologiska \\ vetenskaper, Stockholms Universitet, 10691 Stockholm, Sweden; 3. Global Solutions Upstream, Shell \\ International Exploration and Production, Houston, Texas 77079, U.S.A.; 4. GNS Science, \\ P.O. Box 30-368, Lower Hutt, New Zealand; 5. Earth and Planetary Sciences Department, \\ University of California, Santa Cruz, California 95064, U.S.A.; 6. Department of Earth \\ Sciences, Faculty of Geosciences, Utrecht University, The Netherlands
}

\begin{abstract}
A B S T R A C T
The late Paleocene to early Eocene was marked by major changes in Earth surface temperature and carbon cycling. This included at least two, and probably more, geologically brief $(<200-k$.yr. $)$ intervals of extreme warming, the Paleocene-Eocene thermal maximum (PETM) and the Eocene thermal maximum-2 (ETM-2). The long-term rise in warmth and short-term "hyperthermal" events have been linked to massive injections of ${ }^{13} \mathrm{C}$-depleted carbon into the ocean-atmosphere system and intense global climate change. However, the causes, environmental impact, and relationships remain uncertain because detailed and coupled proxy records do not extend across the entire interval of interest; we are still recognizing the exact character of the hyperthermals and developing models to explain their occurrence. Here we present lithologic and carbon isotope records for a 200-m-thick sequence of latest Paleoceneearliest Eocene upper slope limestone exposed along Mead Stream, New Zealand. New carbon isotope and lithologic analyses combined with previous work on this expanded section shows that the PETM and ETM-2, the suspected $\mathrm{H}-2$, I-1, I-2, and $\mathrm{K} / \mathrm{X}$ hyperthermals, and several other horizons are marked by pronounced negative carbon isotope excursions and clay-rich horizons. Generally, the late Paleocene-early Eocene lithologic and $\delta^{13} \mathrm{C}$ records at Mead Stream are similar to records recovered from deep-sea sites, with an important exception: lows in $\delta^{13} \mathrm{C}$ and carbonate content consistently span intervals of relatively high sedimentation (terrigenous dilution) rather than intervals of relatively low sedimentation (carbonate dissolution). These findings indicate that, over $\sim 6 \mathrm{~m}$.yr., there was a series of short-term climate perturbations, each characterized by massive input of carbon and greater continental weathering. The suspected link involves global warming, elevated greenhouse-gas concentrations, and enhanced seasonal precipitation.
\end{abstract}

Online enhancements: appendix tables and figure.

\section{Introduction}

Earth's surface, at least at high latitudes, warmed by $5^{\circ}-6^{\circ} \mathrm{C}$ from the late Paleocene at ca. $58 \mathrm{Ma}$ to the early Eocene climatic optimum (EECO) between $\sim 53$ and $51 \mathrm{Ma}$ (Zachos et al. 2008; Bijl et 2012.

Manuscript received November 28, 2011; accepted May 11,

* Author for correspondence; e-mail: bss2@rice.edu. al. 2009; Westerhold et al. 2011). Superimposed on this slow temperature rise were a series of geologically brief (<200-k.yr.) intervals of extreme warming coined "hyperthermals," the most prominent example being the Paleocene-Eocene thermal maximum (PETM; Thomas and Zachos 2000; Sluijs et al. 2007; Zachos et al. 2008; McInerney and Wing 2011). The rapid temperature rises correspond

[The Journal of Geology, 2012, volume 120, p. 487-505] () 2012 by The University of Chicago. All rights reserved. 0022-1376/2012/12005-0001\$15.00. DOI: 10.1086/666743 


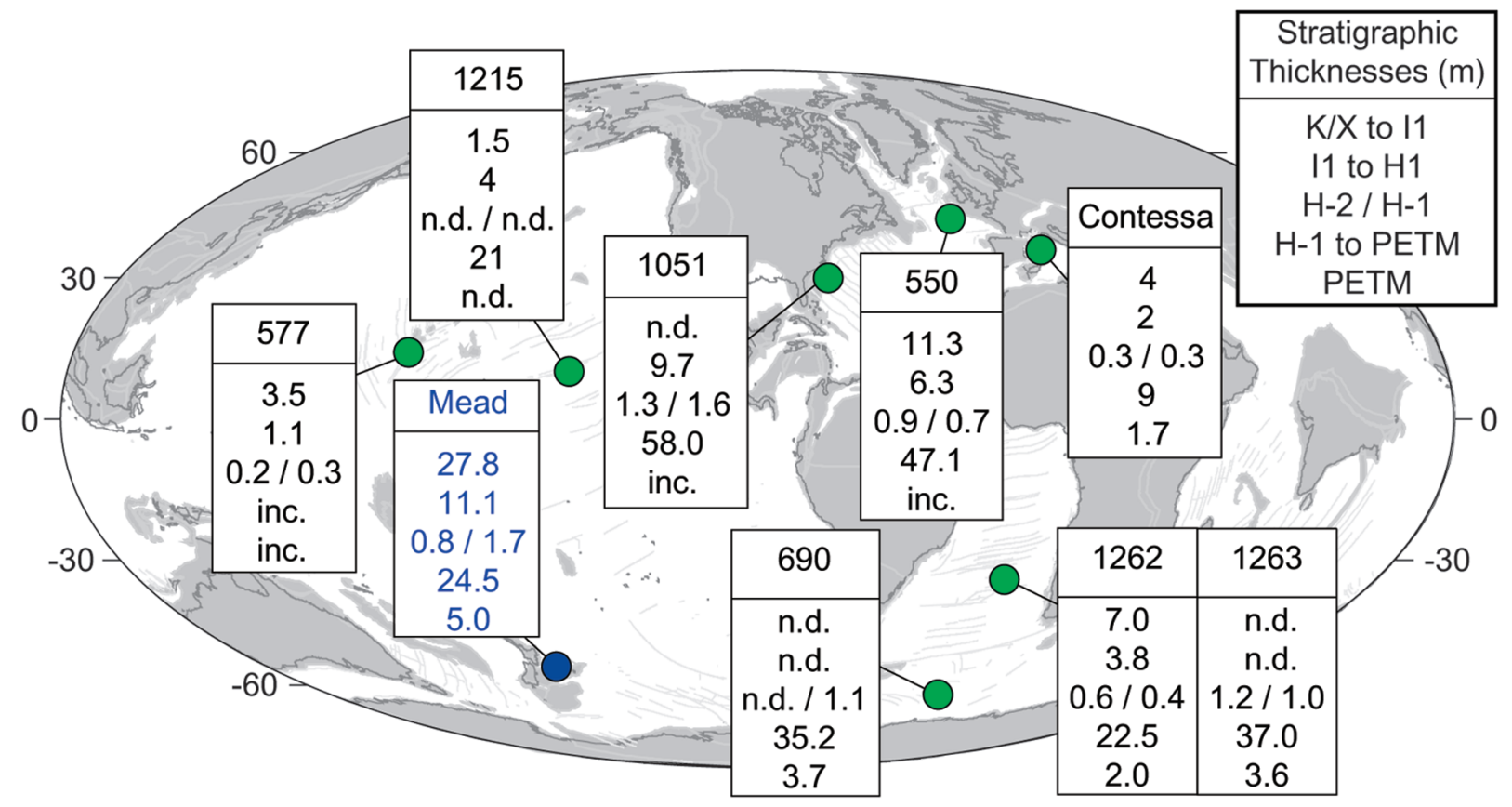

Figure 1. Earth at $53 \mathrm{Ma}$ (http://www.odsn/de/services/paleomap.html) showing multiple locations where early Eocene carbon isotope excursions (CIEs) have been documented in bulk carbonate. These locations include Mead Stream (Hollis et al. 2005a; Nicolo et al. 2007), Ocean Drilling Program (ODP) sites 1262 and 1263 (Lourens et al. 2005; Zachos et al. 2005, 2010; Stap et al. 2009), ODP site 1215 (Leon-Rodriguez and Dickens 2010), Deep Sea Drilling Program sites 550 and 577, ODP sites 690 and 1051 (Cramer et al. 2003), and the Contessa Road Section, Italy (Galeotti et al. 2010). Numbers = stratigraphic thicknesses; inc. = incomplete CIE recovery; n.d. = no data.

closely to pronounced drops in the $\delta^{13} \mathrm{C}$ of carbonbearing material from widespread locations (e.g., Cramer et al. 2003; Lourens et al. 2005, Nicolo et al. 2007; Agnini et al. 2009; Leon-Rodriguez and Dickens 2010; Stap et al. 2010; Zachos et al. 2010). In turn, the negative carbon isotope excursions (CIEs) coincide with intervals of carbonate dissolution in deep-sea sediment sections (Lourens et al. 2005; Zachos et al. 2005, 2010; Leon-Rodriguez and Dickens 2010; Stap et al. 2010). The hyperthermals were probably associated with major inputs of ${ }^{13} \mathrm{C}$ depleted carbon to the ocean and atmosphere (Dickens et al. 1997; Dickens 2011; and above references). Redistribution of carbon between the ocean and atmosphere, such as proposed for a subsequent time interval (50.0-47.6 Ma) of the Eocene (Sexton et al. 2011), seems unlikely given the timing and magnitude of the CIEs and widespread carbonate dissolution at bathyal and abyssal water depths. However, the total number of hyperthermals, their causes, their environmental consequences, and their relationships to one another and to encompassing long-term global change remain uncertain.

Climate models predict a wide range of responses to global warming and massive carbon input (Rand- all et al. 2007; Meehl et al. 2007a, 2007b; Christensen et al. 2007). Some responses can vary significantly, even antithetically, depending on location. For example, several models regarding future climate change show some regions becoming drier and other regions becoming wetter (Held and Soden 2006; Meehl et al. 2007a, 2007b). This aspect of global climate change is particularly relevant to the late Paleocene-early Eocene hyperthermals, because different places might record distinct and sometimes opposing systemic expressions of global warmth or carbon injection. A more complete picture of early Paleogene climate and carbon cycling requires high-resolution, time-correlative, and well-resolved records from multiple locations and environments across Earth.

Ocean Drilling Program (ODP) site 1262 was drilled at $4759 \mathrm{~m}$ water depth on Walvis Ridge, in the south-central Atlantic Ocean (fig. 1). Cores recovered from this site provide a nearly continuous sequence of sediment accumulation from the Maastrichtian through the late Early Eocene (Zachos et al. 2004). For the interval deposited between 58 and $51 \mathrm{Ma}$, orbitally tuned records of physical properties, stable isotope compositions, and ele- 
ment contents have now been generated (Zachos et al. 2004; Lourens et al. 2005; Westerhold et al. 2009; Zachos et al. 2010). These records (fig. 2), with millennial-scale resolution, display paleoceanographic changes during the latest Paleocene and early Eocene in unprecedented detail. Between $\sim 58$ and $\sim 53 \mathrm{Ma}$, there were at least five significant events, each marked by a decrease in $\delta^{18} \mathrm{O}$, a negative CIE, and an increase in Fe content and magnetic susceptibility (MS). The drops in $\delta^{18} \mathrm{O}$ and $\delta^{13} \mathrm{C}$ likely represent ocean warming and inputs of ${ }^{13} \mathrm{C}$ depleted carbon; the highs in Fe content and MS likely represent lows in carbonate content resulting from decreased carbonate ion concentration in seawater and seafloor carbonate dissolution (Zachos et al. 2005, 2009; Zachos et al. 2010). Moreover, it appears the hyperthermals correspond with 400 and 100 k.yr. eccentricity maxima and sometimes occur in pairs (Lourens et al. 2005; Nicolo et al. 2007; Zachos et al. 2010), although debate exists over which eccentricity maximum corresponds to the PETM (Westerhold and Rohl 2009; Hilgen et al. 2010). The five events are tentatively termed, in upward stratigraphic order, PETM, ETM- $/ \mathrm{H}-1, \mathrm{H}-$ 2, I-1, and I-2 (Cramer et al. 2003). Notably, sediment deposited between $\sim 53$ and $\sim 51 \mathrm{Ma}$ at site 1262 (approximately the EECO) lacks published stable isotope records. However, MS highs (Zachos et al. 2004) and unpublished isotope records (Röhl et al. 2005) suggest additional dissolution horizons and possible carbon injection events (fig. 2). The most pronounced event within this later time interval has been coined the " $\mathrm{K}$ " or " $\mathrm{X}$ " event (Cramer et al. 2003; Röhl et al. 2005; Agnini et al. 2009).

Mead Stream, New Zealand (fig. 1), has exposed a 650-m-thick near-continuous upper Cretaceous-middle Eocene sequence (Strong et al. 1995; Hollis et al. 2005a). Previous work at this location and at nearby Dee Stream (Hancock et al. 2003; Nicolo et al. 2007) has documented five negative CIEs associated with clay-rich horizons (marls) across a $\sim 50-\mathrm{m}$ interval that accumulated between $\sim 56$ and $\sim 53 \mathrm{Ma}$ (figs. 2, 3). These five horizons correlate to five negative CIEs found in multiple deep-sea records (Cramer et al. 2003), including the well-resolved, continuous sequence at site 1262 ; they represent the PETM, ETM-2/H-1, H-2, I-1, and I-2 hyperthermals (Nicolo et al. 2007). Unlike at site 1262 , however, the clay-rich horizons resulted from enhanced terrigenous supply (dilution) rather than diminished carbonate accumulation (dissolution) (Nicolo et al. 2007).

The primary objective of this study is to determine whether the previously identified relation- ships between global carbon isotopes and local lithologic variations extend upward into the EECO. We note that the EECO, the warmest million-year interval of the Cenozoic, lacks a formal definition in terms of absolute age and duration; it broadly corresponds to a 1- to 2-m.yr. interval between about 53 and $51 \mathrm{Ma}$. So, do long-term trends and highresolution variations in carbon isotopes and lithology at Mead Stream continue through strata deposited between 53 and 51 Ma? Does the apparent relationship between carbonate dissolution in the deep-sea and terrigenous dilution on the upper slope hold for the entire time interval between 58 and $51 \mathrm{Ma}$ ? What might this imply from an Earth system perspective? Here we address these questions by extending existing lithostratigraphic and chemostratigraphic records at Mead Stream through much of the EECO.

Mead Stream. Location and Section. Amuri Limestone is a succession of calcareous marine sedimentary rocks that outcrop in numerous and widespread locations throughout northeast South Island, New Zealand (e.g., Reay 1993). In eastern Marlborough, Amuri Limestone is a formation within the Muzzle Group (Reay 1993; Hollis et al. 2005a) and consists of four main units or lithotypes: Lower Limestone, Lower Marl, Upper Limestone, and Upper Marl (fig. 2). Each lithotype comprises well-defined decimeter- to meter-scale beds of limestone, marl, or limestone/marl alterations, with greater proportions of marl in both marl units and frequent ribbon cherts within Lower Limestone. The sequence originally accumulated on the upper continental slope of a passive margin at $\sim 55^{\circ}-$ $50^{\circ} \mathrm{S}$ latitude during the late Paleocene through the late Eocene (Reay 1993; Strong et al. 1995; Hollis et al. 2005a). This slope was northwest-facing and formed the southeastern margin of a large reentrant on the otherwise north-facing continental margin of proto-New Zealand; regions east of this reentrant were isolated from coarser terrigenous clastic sediment that was deposited further to the west during the Paleocene and Eocene (Crampton et al. 2003). Subsequently, rocks of Amuri Limestone were uplifted, faulted apart, and, in most places, rotated about vertical axes so that beds have high dip angles (Reay 1993; Strong et al. 1995; Crampton et al. 2003; Hollis et al. 2005a).

A succession of streams in northeast Clarence River Valley cut Amuri Limestone approximately perpendicular to strike (Reay 1993). At Mead Stream, a narrow and deep gorge exposes $\sim 390 \mathrm{~m}$ of Amuri Limestone. The beds have a $\sim 50^{\circ}$ northwest dip and excellent outcrop. A series of studies (Strong et al. 1995; Hollis et al. 2005a; Nicolo et 


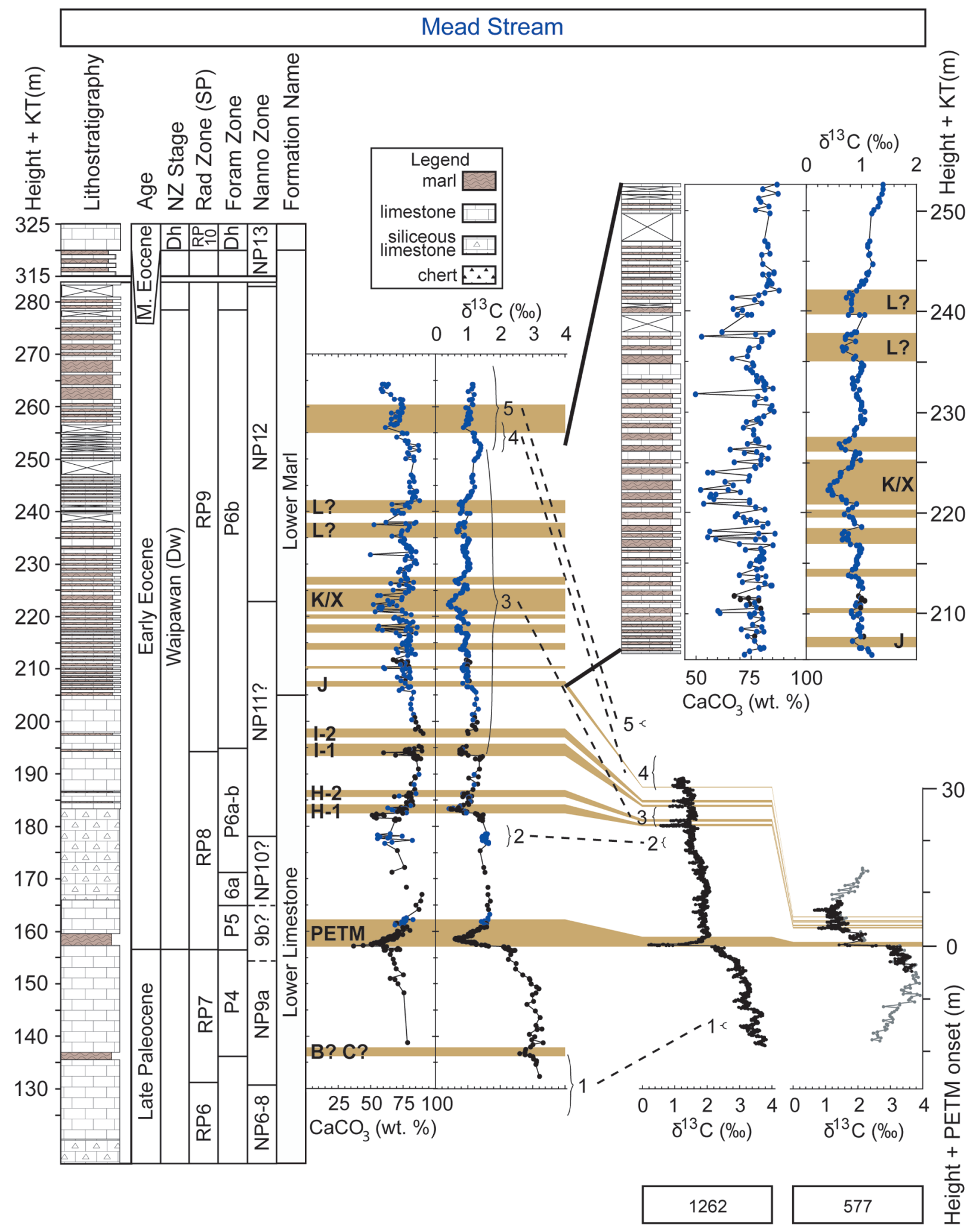


al. 2007) have provided a good stratigraphic framework for this section, with a zero datum set at the $\mathrm{K} / \mathrm{T}$ boundary. Lower Limestone spans from 116 to $204 \mathrm{~m}$ and includes the PETM, H, and I events; it is conformably overlain by Lower Marl, which spans from 204 to $320 \mathrm{~m}$. Collectively, the two units encompass deposition on a southern middle latitude upper slope from the late Paleocene through the early Eocene (Strong et al. 1995).

Hyperthermals and Marl Horizons. Lower Limestone at Mead Stream has numerous thin $(<5 \mathrm{~cm})$ marls between limestone beds. Across five or six intervals, overall clay content increases so that the marl beds thicken and the limestone beds become more marly, resulting in relatively thick $(>10 \mathrm{~cm})$ marl-dominated intervals (Hollis et al. 2005a; Nicolo et al. 2007). Based on microfossil datums and carbon isotope stratigraphy, four of these intervals correlate to hyperthermal events documented elsewhere (figs. 1, 2): the PETM (157.3 m), ETM2/H-1 $(182.3 \mathrm{~m}), \mathrm{H}-2(185.7 \mathrm{~m})$, and I-1 (193.4 m). A fifth interval, representing the I-2 event, is believed to occur at 197-198 m, but has not been sampled because this portion of the section is overgrown by vegetation. A sixth interval, at about $138 \mathrm{~m}$ and below the PETM, was correlated tentatively to either the "B1-B2" or "C1-C2" event (Hollis et al. 2005a) found in several deep-sea locations (Cramer et al. 2003). Consistent with other records, the most prominent negative CIE $(\sim 2.5 \%)$ represents the PETM (Hancock et al. 2003; Hollis et al. 2005a). Also consistent with records from other localities (Cramer et al. 2003; Stap et al. 2009; Zachos et al. 2010), the $\mathrm{H}$ events and I events (the latter based on work at nearby Dee Stream) manifest as pairs of CIEs with diminishing magnitude and probably separated by about 100 k.yr. (Nicolo et al. 2007).

Increased accumulation of terrigenous material characterizes the PETM in several sequences from continental margin settings (Schmitz et al. 2001;
Crouch et al. 2003; Giusberti et al. 2007; John et al. 2008; Galeotti et al. 2010; Höntzsch et al. 2011) and high latitudes (Sluijs et al. 2008). This also appears to be the case at Mead Stream (Nicolo et al. 2007), and can be ascertained from straightforward sedimentation rate calculations. The negative CIE associated with the PETM (from onset through partial recovery) occurred within 120-220 k.yr. (Westerhold et al. 2009; Murphy et al. 2010) and is $\sim 5 \mathrm{~m}$ thick at Mead Stream. This gives a compacted sedimentation rate across the event of $2.3-4.2 \mathrm{~cm} / \mathrm{k}$.yr. The ETM2/H-1 event occurred $\sim 1.8 \mathrm{Myr}$ after the PETM (Westerhold et al. 2009) and is approximately $24.5 \mathrm{~m}$ upsection. This gives a "background" compacted sedimentation rate between the events of $\sim 1.2 \mathrm{~cm} / \mathrm{k}$.yr. Increased accumulation of terrigenous material occurred across each of the five hyperthermals identified at Mead Stream to date (fig. 3). By contrast, the same events at site 1262 , and at other open ocean locations such as site 1215 , are marked by lower sediment accumulation compared to background rates and obvious signs of carbonate dissolution (Zachos et al. 2005; LeonRodriguez and Dickens 2010; Stap et al. 2010). Thus, with available data, there is an "accordion" effect between the records at site 1262 and at Mead Stream. The long-term sedimentation rate trends from 56 to $52 \mathrm{Ma}$ were similar at both sites (the distance between the PETM and ETM-2/H-1 is 22.5 $\mathrm{m}$ at ODP site 1262). However, the hyperthermals are compressed at site 1262 but expanded at Mead Stream (Nicolo et al. 2007).

The EECO is fairly condensed at site $1262(\sim 8 \mathrm{~m}$ thick from $\sim 110-102 \mathrm{mcd}$ ), as would be predicted if the series of MS peaks at this location (figs. 3, A1, available in the online edition or from the Journal of Geology office) represent multiple carbonate dissolution horizons. This leads to an interesting and testable hypothesis for the Mead Stream section: Lower Marl represents a greatly expanded

Figure 2. Lower Paleogene sequences at Ocean Drilling Program (ODP) site 1262 and at Mead Stream. Bulk carbonate $\delta^{13} \mathrm{C}$ data for ODP site 1262 are from Zachos et al. (2010). Formation names, lithology, and biostratigraphy for Mead Stream are from Hollis et al. (2005a) with minor biostratigraphic modification. Bulk carbonate $\delta^{13} \mathrm{C}$ data for Mead Stream represent predominantly new samples (i.e., blue circles mark new samples analyzed in this study, whereas black circles mark samples analyzed in previous studies). Also included are bulk carbonate $\delta^{13} \mathrm{C}$ records for DSDP site 577 (gray: Shackleton et al. 1985; black: Cramer et al. 2003). The tie-points between site 1262 and Mead Stream are based mostly on the $\delta^{13} \mathrm{C}$ records. However, some first and last occurrences (FOs and LOs) of foraminiferal and nannofossil bio-datums exist at the two locations (Zachos et al. 2004; Hollis et al. 2005a; Agnini et al. 2007) and provide additional chronostratigraphic constraints (dotted lines). These are: $1=$ Discoaster multiradiatus FO; $2=$ Tribrachiatus orthostylus FO; $3=$ Discoaster lodoensis FO; $4=$ Morozovella aequa LO, and $5=$ T. orthostylus LO. Height at Mead Stream is relative to a zero datum at the Cretaceous-Tertiary boundary. Height at sites 1262 and 577 is relative to a zero datum at the Paleocene-Eocene thermal maximum onset. Tan intervals represent individual carbon isotope excursions. 


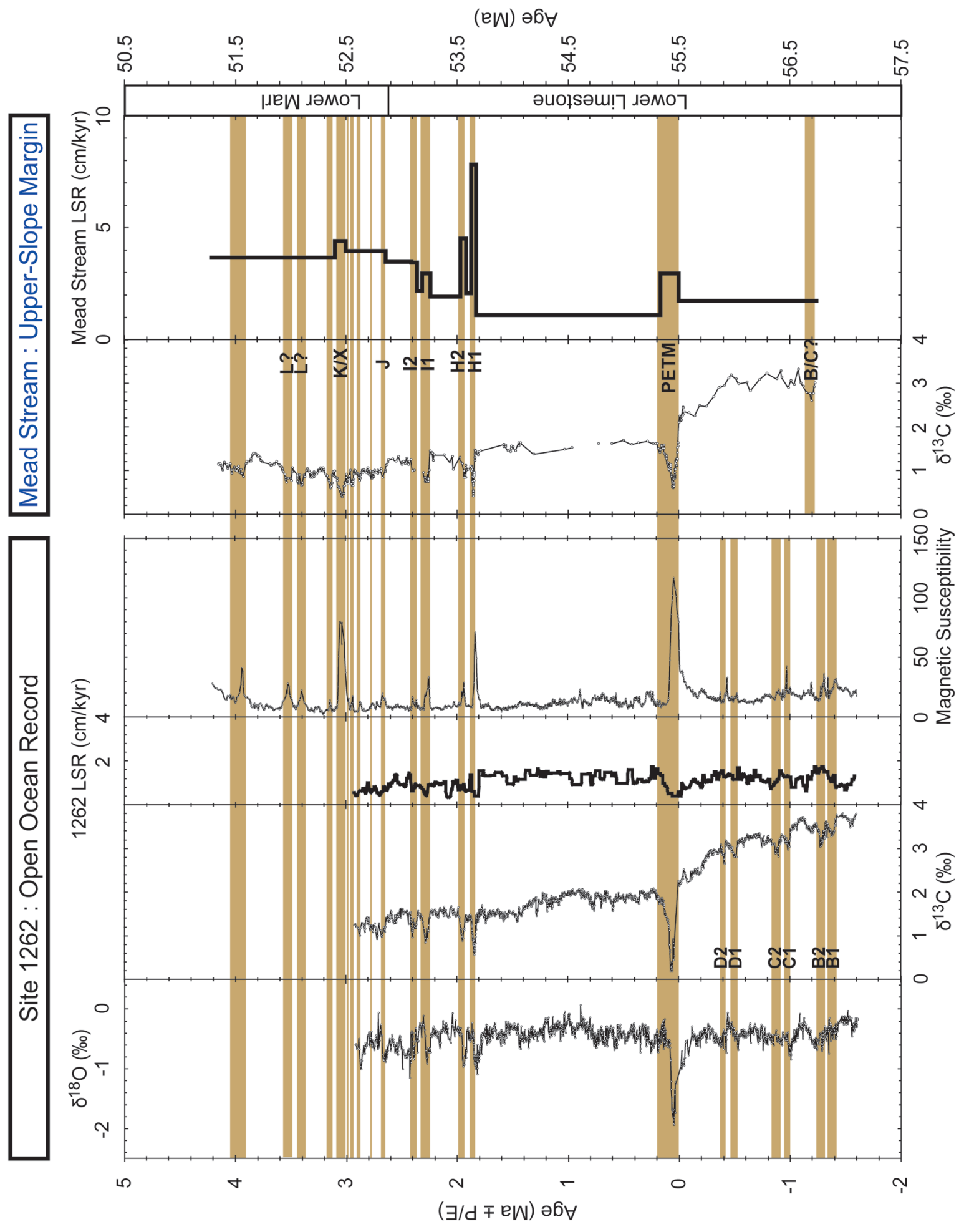


EECO interval caused by numerous episodes of excess terrigenous supply related to warmer conditions. That is, throughout the early Paleogene, there are coeval condensed sections in open-ocean settings (e.g., at site 1262) and expanded sections in certain continental margin settings (e.g., at Mead Stream).

\section{Methods}

Stratigraphic Log and Samples. Lower Limestone at Mead Stream has been logged in detail, generally at the centimeter scale (Hollis et al. 2005a; Nicolo et al. 2007). We have continued such logging through Lower Marl until $285 \mathrm{~m}$ above the K/T boundary. Deformation (e.g., boudinage, shear, faults, and isoclinal folds) complicates logging above this level, although good stratigraphic sections do exist further upstream, as well as along other streams in Clarence River Valley (Reay 1993; Hollis et al. 2005b).

Lower Marl is well bedded (fig. 4A). Bed packages were numbered, and individual beds were described as one of four lithologies: limestone, siliceous limestone, marl, or marly limestone (figs. 3, 5). A total of 283 new rock samples (table A1, available in the online edition or from the Journal of Geology office) were chiseled from outcrops (typically one per bed). Most came from Lower Marl between 205 and 265 $\mathrm{m}$. The other samples were collected to fill gaps in existing records across middle and upper portions of Lower Limestone.

Analyses. Weathering rinds were removed from samples using a rock saw. The remaining material was then powdered and homogenized in a tungsten carbide rock mill and freeze-dried. Splits of samples then were analyzed for $\mathrm{CaCO}_{3}$ content and stable isotopes. For the first measurement, we used the "carbonate bomb" technique (Dunn 1980), which has a better than $1.5 \%$ analytical precision (table A1). Stable isotopes were determined at the Stable Isotope Laboratory, University of California, Santa Cruz. Between 50 and $100 \mu \mathrm{g}$ of powder were analyzed using an Autocarb device coupled to a Kiel IV carbonate device and/or Prism or Optima mass spectrometer. Carbon isotope values were calibrated to the Vienna PeeDee belemnite standard using NBS-18, NBS-19, and an in-house standard Carrara marble (table A1). Analytical precision for the Kiel IV carbonate device is better than $\pm 0.025 \%$, and analytical precision for the Prism or Optima mass spectrometer is better than $\pm 0.05 \%$. Stable oxygen isotope values were measured to a precision of $\pm 0.1 \%$, but all samples are significantly depleted in ${ }^{18} \mathrm{O}$ (average of $-3.5 \%$ ). This suggests oxygen isotope exchange with meteoric water, so these analyses are not discussed further.

\section{Results}

Bedding. Lower Limestone is composed of centimeter- to decimeter-scale beds dominated by ribbon chert between 116 and $120 \mathrm{~m}$ and by limestone between 120 and $166 \mathrm{~m}$. Ribbon chert beds then reappear for $\sim 9 \mathrm{~m}$ between 166 and $175 \mathrm{~m}$, or just above the PETM. Typically, the beds within Lower Limestone are separated by marl partings or thin $(<5 \mathrm{~cm})$ marl horizons. However, six horizons with multiple marl beds, including the PETM (fig. 4B), occur within this unit (Hollis et al. 2005a; Nicolo et al. 2007).

Starting at the base of Lower Marl and continuing through this unit, marl beds become thicker and more common. The marl beds range from 7 to 76 $\mathrm{cm}$ thick, with an average thickness of $30 \pm 17 \mathrm{~cm}$ at $1 \sigma$. Lower Marl thus differs from Lower Limestone because marl beds comprise $\sim 50 \%$ of the outcrop (figs. 5, 6) and because there are no ribbon cherts.

Carbonate Content. Carbonate contents range between $36 \%$ and $91 \%$ with a mean of $73 \%$ and a standard deviation $(1 \sigma)$ of $9.3 \%$ across all early Paleogene samples examined to date at Mead Stream (table Al; fig. 2). Partitioned by lithology, the means and deviations of $\mathrm{CaCO}_{3}$ contents are $64 \% \pm 7.2 \%(n=98), 69 \% \pm 7.0 \%(n=24)$, and $76 \% \pm 10.2 \%(n=389)$ for marl, marly limestone, and limestone, respectively. Carbonate content is generally higher and less variable in samples spanning Lower Marl $(75 \% \pm 8.1 \% ; n=266)$ compared

Figure 3. Late Paleocene to early Eocene records at site 1262 (Zachos et al. 2004, 2010) and at Mead Stream, with likely correlations to carbon isotope excursions (CIEs) documented by Cramer et al. (2003). The age model generated for this study is consistent with available age datums (e.g., site 1262 , top of C23n $=50.78 \mathrm{Ma}$, X-event $=+3 \mathrm{~m}$.yr. from Paleocene-Eocene thermal maximum onset; Zachos et al. 2004; Agnini et al. 2007). Compacted linear sedimentation rates (LSRs) are also included for both site 1262 and Mead Stream (see text). Note that condensed sections at Ocean Drilling Program site 1262 correspond to expanded sections at Mead Stream, particularly across each hyperthermal. 

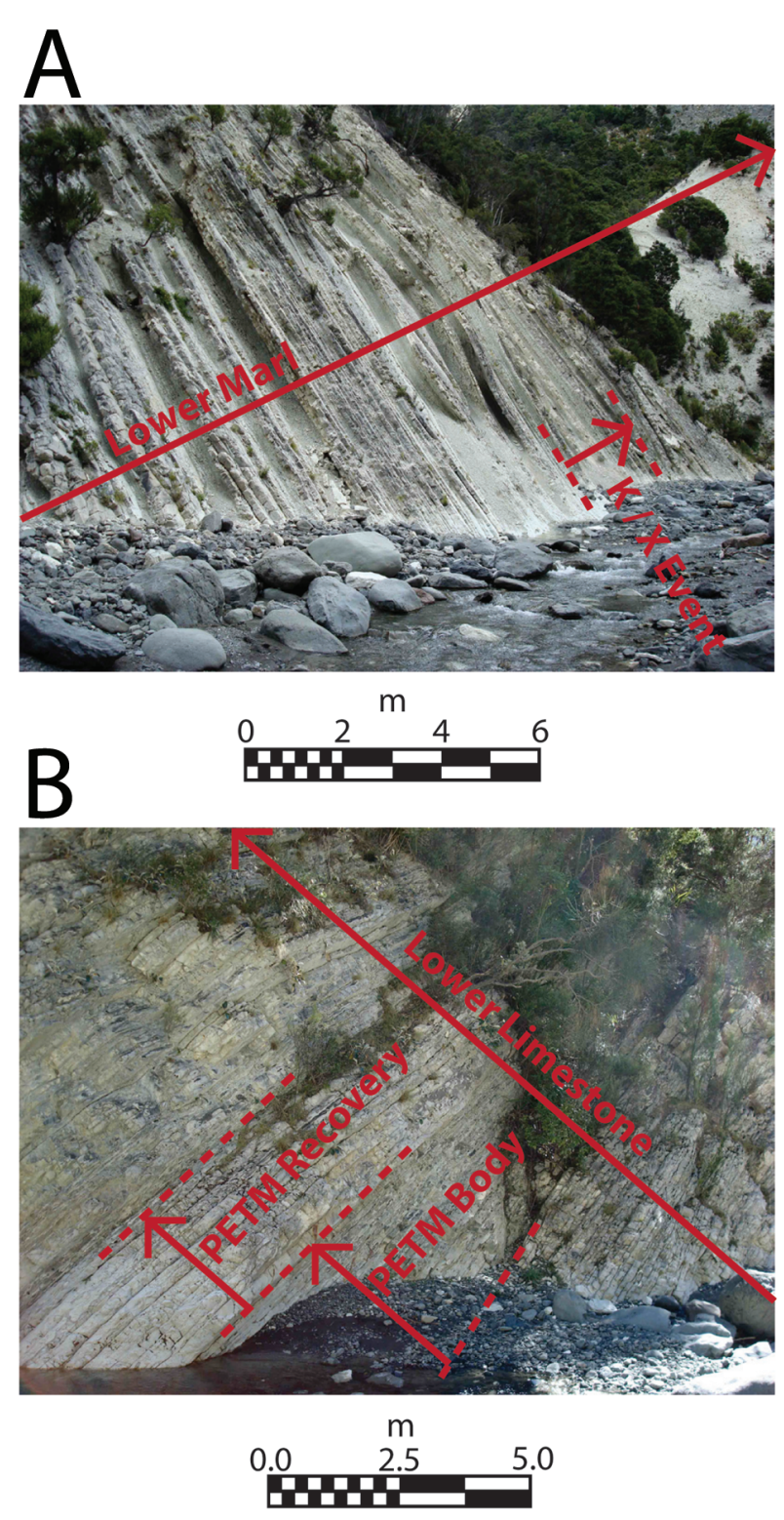

Figure 4. Photographs at Mead Stream showing $(A)$ the $\mathrm{K} / \mathrm{X}$ event within Lower Marl (note that this is not the full extent of Lower Marl) and $(B)$ the Paleocene-Eocene thermal maximum (PETM) within Lower Limestone.

to those spanning Lower Limestone $171 \% \pm$ $10.3 \% ; n=280$ ). This reflects two aspects of the current data set. Sampling of Lower Limestone focused on identification of hyperthermal events and includes detailed (cm-scale) sampling across these clay-rich intervals; this sampling also contains ribbon cherts, where the presence of siliceous material lowers carbonate content (Hollis et al. 2005a; Nicolo et al. 2007, 2010). Once these considerations are accounted for, the variability in carbonate content across moderately short thicknesses is greater in Lower Marl due to the higher frequency of marl beds (figs. 5, 6). Lastly, a general low in carbonate content occurs within Lower Marl from about 221 to $224 \mathrm{~m}$ (fig. 5A).

Carbon Isotopes. Bulk carbonate $\delta^{13} \mathrm{C}$ varies between $3.35 \%$ and $0.40 \%$ across the studied interval (fig. 2). The most enriched $\delta^{13} \mathrm{C}$ values $\left(2.59 \%{ }^{-}\right.$ $3.31 \%$ o occur within the basal part of the record (from 132.4 to $151.8 \mathrm{~m}$ ). By contrast, the most depleted $\delta^{13} \mathrm{C}$ values are typically in the middle to upper part of the record (205 to $255 \mathrm{~m}$ ). Values become more depleted from 150 to $222 \mathrm{~m}$ and generally become more enriched above $222 \mathrm{~m}$. Superimposed on these long-term trends are multiple negative CIEs, defined as significant drops in $\delta^{13} \mathrm{C}$ across short intervals $(<5 \mathrm{~m})$. The lowest $\delta^{13} \mathrm{C}$ values of $\sim 0.40 \%$ represent the most extreme CIEs.

The five or six obvious marl-rich horizons within Lower Limestone (figs. 2, 3), are each associated with a significant CIE (Hollis et al. 2005a; Nicolo et al. 2007). Additionally, a series of at least ten CIEs characterize the lower part of Lower Marl, between 205 and $261 \mathrm{~m}$ (table A2, available in the online edition or from the Journal of Geology office; figs. 2, 3, A1). The magnitudes of these excursions within Lower Marl reach up to $0.6 \%$. Of these, the most pronounced coincides with the prominent recessed marl-rich horizon centered at $222.4 \mathrm{~m}$ (figs. $4 A, 5 A$ ). However, the other CIEs within Lower Marl also correspond to marl-rich intervals of lower $\mathrm{CaCO}_{3}$ content. Importantly, however, the $\delta^{13} \mathrm{C}$ does not depend on rock type at the decimeter-scale (figs. 5, 6); that is, the $\delta^{13} \mathrm{C}$ records are "smooth" across obvious changes in lithology. This strongly suggests that the $\delta^{13} \mathrm{C}$ trends reflect primary signals in carbonate, even though the carbonate content can vary considerably.

\section{Discussion}

Age and Correlation of the Mead Stream Section. An initial age model for the studied interval at Mead Stream can be derived using available foraminifera, radiolarian, and nannofossil datums (Strong et al. 1995; Hollis et al. 2005a). However, many key species have patchy occurrences, which reflects a combination of poor preservation and difficulties recovering microfossils from these indurated rocks. Some first and last occurrences (FOs, LOs) also may be diachronous with those at sites from lower latitudes, which underpin standard biozones for the Early Paleogene (e.g., Berggren et al. 1995).

Four nannofossil events (Agnini et al. 2007) and 
one foraminiferal event (Zachos et al. 2004) provide a first-order stratigraphic correlation between Mead Stream and site 1262. The first occurrence of Discoaster multiradiatus (base of nannofossil zone NP9a) occurs between 125.0 and $136.5 \mathrm{~m}$ at Mead Stream and between 154.61 and $155.66 \mathrm{mcd}$ at site 1262. The FO of Tribrachiatus orthostylus (approximate base of NP11) occurs between 176.0 and $180.0 \mathrm{~m}$ at Mead Stream and between 118.3 and $119.5 \mathrm{mcd}$ at site 1262 . The FO of Discoaster lodoensis (base of NP12) occurs between 195.0 and $252.0 \mathrm{~m}$ at Mead Stream and between 113.5 and $117.3 \mathrm{mcd}$ at site 1262 . The last occurrence (LO) of Tribrachiatus orthostylus (base of NP13) occurs at or above $252 \mathrm{~m}$ at Mead Stream and between $96.9-97.9 \mathrm{mcd}$ at site 1262 . The LO of Morozovella aequa occurs between 251.4 and $257.0 \mathrm{~m}$ at Mead Stream and between 105.0 and $111.4 \mathrm{mcd}$ at site 1262. Based on these biostratigraphic datums, the section from 125.0-136.5 to 251.4-257.0 $\mathrm{m}$ at Mead Stream (figs. 2, 3) correlates to the section from $154.6-155.7$ to $105.0-111.4 \mathrm{mcd}$ at site 1262 (note the height axis at Mead Stream has opposite stratigraphic direction from the depth axis at site 1262). These datums provide a general chronostratigraphic framework for correlation of carbon isotope records.

Bulk carbonate carbon isotope records can be used to align widely separated marine sediment sections deposited during the early Paleogene (e.g., Shackleton and Hall 1984, 1990). The underlying rationale is that carbon cycles relatively fast $<<2000$ years) within the exogenic carbon cycle and that the early Paleogene exogenic carbon cycle was characterized by large-amplitude variations in carbon inputs and outputs of different $\delta^{13} \mathrm{C}$. With a basic biostratigraphic template, carbon isotope stratigraphy provides a robust basis for aligning early Paleogene sediment records at Mead Stream and at site 1262 (table A3, available in the online edition or from the Journal of Geology office; figs. $2,3)$. Presently, the sections at Mead Stream and at site 1262 cannot be correlated via carbon isotope stratigraphy for sediment younger than $52.6 \mathrm{Ma}$, because the isotope record for this interval at site 1262 has yet to be completed. However, the general trends in $\delta^{13} \mathrm{C}$ at Mead Stream can be correlated to those at site 577 in the North Pacific (Shackleton et al. 1985; Cramer et al. 2003; fig. 2). The broad correlation of records at the two sites leads to important notions concerning carbon cycling and CIEs during the early Paleogene.

Carbon Isotope Excursions. Between 56.5 and 52.5 $\mathrm{Ma}$, a long-term drop in $\delta^{13} \mathrm{C}$ marks carbonate records at Mead Stream on the upper continental slope and at multiple sites in the deep ocean. Between 52.5 and $51.3 \mathrm{Ma}$, a long-term rise in $\delta^{13} \mathrm{C}$ marks these same records. Superimposed on both intervals are a series of geologically brief $\mid<200$ k.yr.) negative CIEs. The most prominent examples are the PETM (fig. $4 B$ ) and ETM-2/H-1, but there are at least six and probably more short excursions, each characterized by a CIE with a magnitude up to $0.6 \%$ (figs. $3, \mathrm{~A} 1$ ).

Beyond five CIEs within the $\sim 56$ to $53 \mathrm{Ma}$ old Lower Limestone (Hollis et al. 2005a; Nicolo et al. 2007), four CIEs documented elsewhere occur at Mead Stream (figs. 3, A1). About $20 \mathrm{~m}$ below the PETM, at $\sim 136.5-138.0 \mathrm{~m}$ and $\sim 56.7 \mathrm{Ma}$, a marlrich horizon ("Mudstone $C^{\prime \prime}$ ) has low carbonate contents and a 0.5\% CIE (Hollis et al. 2005a). This mudstone probably corresponds to either the B or C CIE (Cramer et al. 2003). However, we cannot deduce which one with available information. At the transition from Lower Limestone to Lower Marl ( 207 $\mathrm{m}$ and $\sim 52.9 \mathrm{Ma})$, there is a $-0.3 \%$ "step" in $\delta^{13} \mathrm{C}$ values. This very likely corresponds to the J CIE (Cramer et al. 2003; Zachos et al. 2010). The prominent recessed marl within Lower Marl ( 222 $\mathrm{m}$ and $\sim 52.5 \mathrm{Ma}$ ) almost assuredly correlates with the K CIE (Cramer et al. 2003; Agnini et al. 2009) and X horizon at site 1262 (Röhl et al. 2005; figs. 3-5). This is because it marks the extreme low in Paleogene $\delta^{13} \mathrm{C}$ records, as observed elsewhere (Cramer et al. 2003; Röhl et al. 2005; Agnini et al. 2009). One of two additional CIEs with magnitudes of $-0.3 \%$ and $-0.2 \%$ that occur between 235 and $243 \mathrm{~m}$ or 52.1 and 51.9 Ma may also correlate to the L CIE (Cramer et al. 2003).

The J CIE initiates a general long-term $\delta^{13} \mathrm{C}$ low at site 1262 (Zachos et al. 2010) and at Mead Stream. This roughly corresponds to the start of the EECO as shown in global compilations of oxygen and carbon isotopes (e.g., Zachos et al. 2001). As such, the J CIE might provide a good chronostratigraphic marker for the onset of the EECO. However, without invoking circular reasoning for links between Earth surface temperature and siliciclastic inputs (below), we hesitate to define the start of EECO with records from Mead Stream.

The K/X event seems to represent a prominent early Paleogene hyperthermal within the longer duration of the EECO, although this inference remains unclear with current records at Mead Stream and elsewhere, as well as with uncertain definitions for "hyperthermal." Irrespective, at Mead Stream, the marl and CIE corresponding to the $\mathrm{K} / \mathrm{X}$ event is only the most prominent example within a $\sim 1.5$ m.yr. time window. A series of marl-rich horizons with negative CIEs of magnitude $0.2 \%-0.6 \%$ char- 

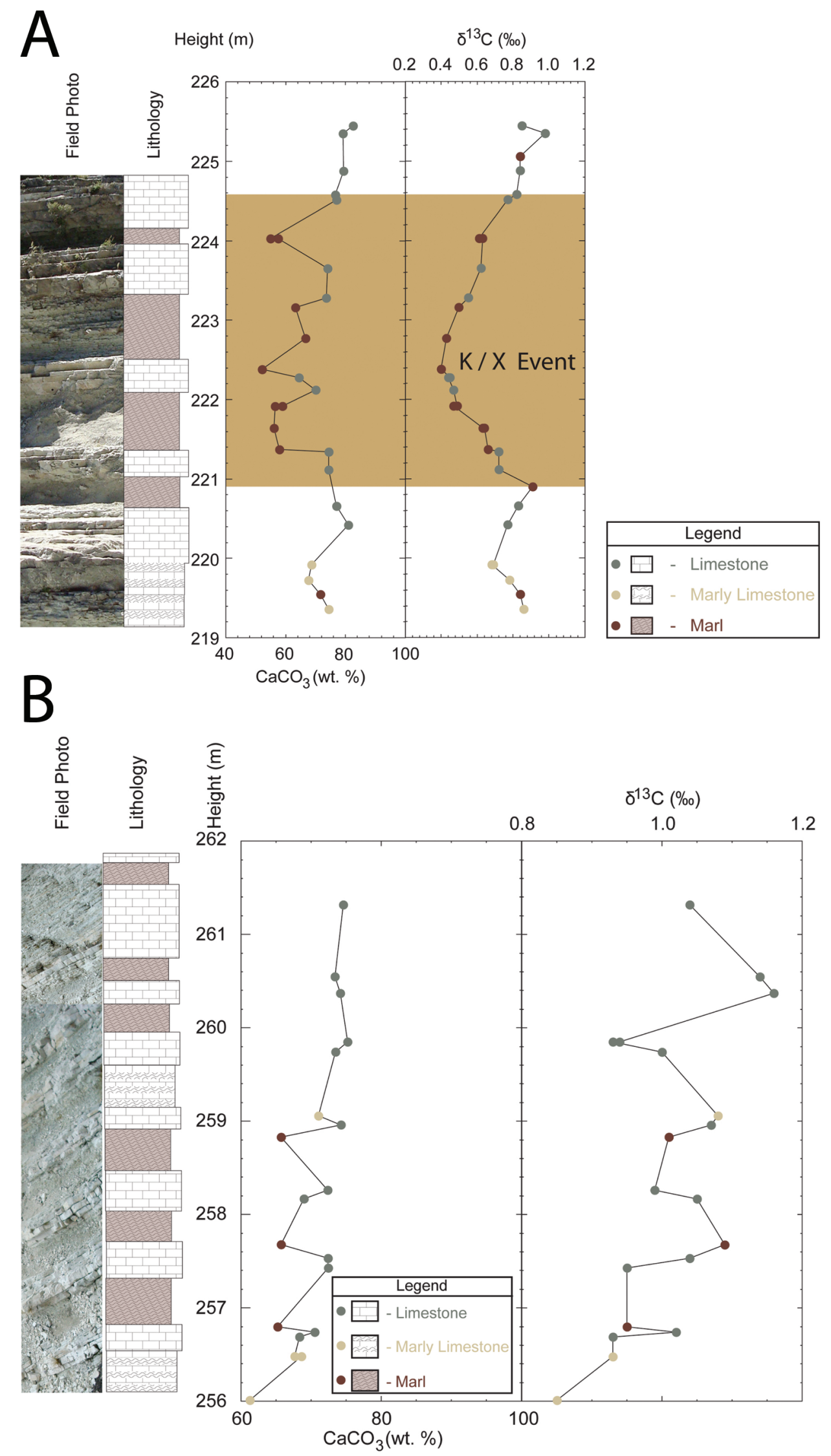
acterize this portion of the sedimentary record / table A2, available in the online edition or from the Journal of Geology office; figs. 2, 3, A1). Furthermore, changes in the $\delta^{13} \mathrm{C}$ record at Mead Stream appear to correlate with variations in the MS record at site 1262 from about 56.7 to $51.3 \mathrm{Ma}$ (figs. 3, A1). We therefore propose, on the character and stratigraphic positions of $\delta^{13} \mathrm{C}$ changes at Mead Stream and at site 1262, supplemented by MS variations at site 1262 , that there were at least four CIEs between $\mathrm{J}$ and $\mathrm{K} / \mathrm{X}(52.8-52.3 \mathrm{Ma})$ and at least four CIEs younger than $\mathrm{K} / \mathrm{X}$, one of the latter which corresponds to the $\mathrm{L}$ event documented by Cramer et al. (2003). Collectively, these CIEs broadly span the loosely defined EECO and may have been overlooked in many deep-sea sections given sampling resolution and the overwhelming occurrence of condensed sections in the deep-sea environment over this time interval. In summary, the EECO at Mead Stream appears to correspond to multiple CIEs in short succession. Despite our new records, the exact number of CIEs between 56.5 and 51.5 $\mathrm{Ma}$, and their absolute ages remain uncertain without firmer stratigraphy and without high-resolution $\delta^{13} \mathrm{C}$ records at multiple sites throughout the entire time interval.

Generic Cause of Marl-Rich Intervals at Mead Stream. The general lithologic transition from chert-bearing limestone to "pure" limestone within Lower Limestone, and from "pure" limestone to alternating marl-limestone beds across the Lower Limestone and Lower Marl boundary broadly coincides with the long-term warming between 58 and $51 \mathrm{Ma}$ (Zachos et al. 2008; Bijl et al. 2009; Westerhold et al. 2011). The chert, deposited originally as diatoms and radiolarians, is inferred to reflect cooler water temperatures (Hollis 2002; Hollis et al. 2003, 2005a), similar to the distribution of pelagic sediments in the present-day high-latitude oceans. This contrasts with the controls on equatorial chert deposition, which appears to occur during times of warming such as the EECO (Muttoni and Kent 2007). During the $\sim 7$ m.yr. of warming, biogenic silica content decreased and limestones became pure carbonate, sediment originally deposited as calcareous nannofossils and foraminifera. The subsequent increase in clay content reflects greater input of terrigenous-sourced material from enhanced seasonal precipitation, probably combined with greater chemical weathering (Robert 2004).

For Amuri Limestone, marl-rich intervals correspond to anomalously warm conditions (Hollis et al. 2005a). They are rare in Lower Limestone, when background conditions were cooler (Hollis et al. 2005a; figs. 2, 3). Indeed, in Lower Limestone, significant marl units mark the known and suspected hyperthermal events (Nicolo et al. 2007). However, they become a major component of the lithology during deposition of Lower Marl (fig. 5), which roughly corresponds to the warmer background conditions of the EECO.

The correlation of the early Paleogene section at Mead Stream to that at site 1262 (Zachos et al. 2004, 2010) and other locations (Cramer et al. 2003) allows comparison of sedimentation rates across multiple sites (Nicolo et al. 2007). Throughout the time interval of interest, average $\mathrm{CaCO}_{3}$ contents can be estimated at site 1262 using published MS data (Zachos et al. 2004). The basic idea here is that a two-component sediment system /carbonate and clay) characterizes the early Paleogene record at site 1262 and that MS relates directly to clay abundance. Assuming clay accumulation at this openocean site does not change much in time, the MS records (and clay contents), along with biostratigraphic datums, therefore provide first-order estimates on sedimentation rate (Lourens et al. 2005; Nicolo et al. 2007; Stap et al. 2009). This approach indicates that the ETM-2, H-2, I-1, and K/X events began 1.8, 1.9, 2.2, and $3.0 \mathrm{~m}$.yr. after the onset of the PETM, respectively, in line with estimates based on cyclostratigraphy (Agnini et al. 2007; Westerhold and Röhl 2009). It also implies that highs in MS (and lows in carbonate) across these events at site 1262 represent lower carbonate accumulation (i.e., carbonate dissolution).

An interval of low carbonate content marks the PETM in numerous marine sections. However, previous work suggests the origin of this interval differs: it generally relates to carbonate dissolution and lower sedimentation rates in the deep ocean (e.g., Lourens et al. 2005; Zachos et al. 2005; LeonRodriguez and Dickens 2010; Stap et al. 2010; Zachos et al. 2010) and carbonate dilution and higher sedimentation rates along continental margins (Schmitz et al. 2001; Hollis et al. 2005a, 2005b;

Figure 5. Photographs with accompanying records of lithology, carbonate content, and stable carbon isotopes across two short intervals of Lower Marl at Mead Stream: $(A)$ the K/X event and $(B)$ a typical Lower Marl interval above K/X. 


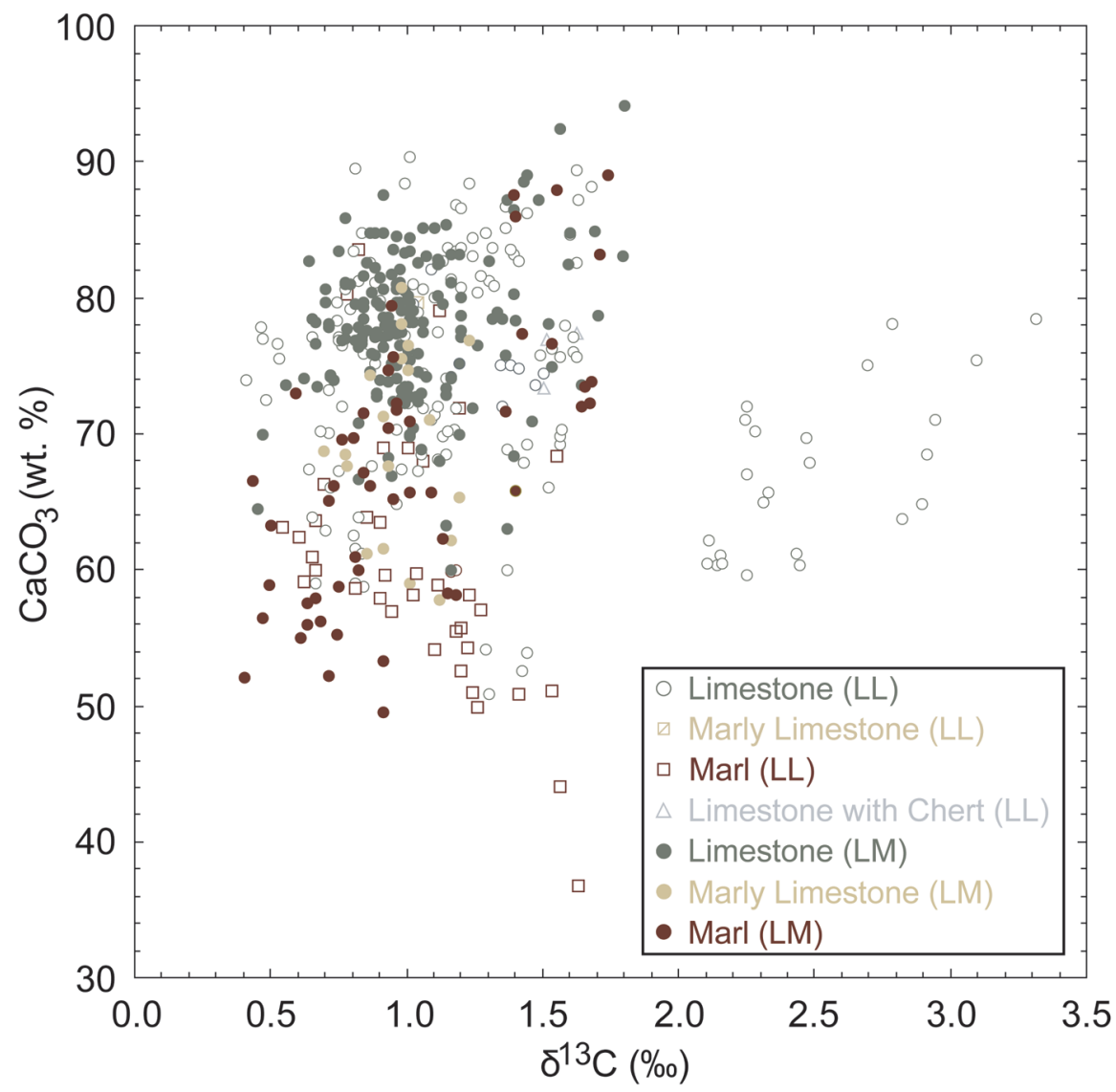

Figure 6. Stable carbon isotope compositions versus carbonate content for all data generated at Mead Stream to date. Note that there is very little correlation $\left(y=-0.0008 x+1458.375 ; r^{2}=0.0003\right)$ across all samples but that different lithologies have different bulk $\delta^{13} \mathrm{C}$ and $\mathrm{CaCO}_{3}$ contents. $\mathrm{LL}=$ Lower Limestone; $\mathrm{LM}=$ Lower Marl.

Giusberti et al. 2007; Nicolo et al. 2007; John et al. 2008) and at high latitudes (Sluijs et al. 2008).

Our sedimentation rate estimates indicate that the same phenomenon occurs throughout much of the EECO. That is, clay-rich horizons mark the J, $\mathrm{K} / \mathrm{X}, \mathrm{L}$, and other CIEs in multiple sections in different environments. At site 1262, and elsewhere (e.g., site 1215), these represent condensed intervals of time and carbonate dissolution (Stap et al. 2009; Leon-Rodriguez and Dickens 2010). At Mead Stream, they represent expanded intervals of time and terrigenous dilution.

The difference in sedimentation between environments can be demonstrated with comparisons of thicknesses between and including horizons with low carbonate content (fig. 1). For example, applying such an approach shows different compacted sedimentation rate "curves" at site 1262 and Mead Stream (fig. 7). More specifically, compacted sedimentation rates were similar between the PETM and the ETM-2/H-1 onset $(1.3 \mathrm{~cm} / \mathrm{k}$.yr. at site 1262 ; $1.2 \mathrm{~cm} / \mathrm{k} . y r$. Mead Stream), but substantially dif- ferent during the PETM $(0.4 \mathrm{~cm} / \mathrm{k}$.yr. at site 1262 ; $3.0 \mathrm{~cm} / \mathrm{k} . y r$. at Mead Stream), the ETM-2/H-1 $(0.4$ $\mathrm{cm} / \mathrm{k} . y r$. at site $1262 ; 7.9 \mathrm{~cm} / \mathrm{k} . y r$. at Mead Stream), between the $\mathrm{H}-2$ and $\mathrm{K} / \mathrm{X}(0.8 \mathrm{~cm} / \mathrm{k}$.yr. at site 1262 ; $3.2 \mathrm{~cm} / \mathrm{k}$.yr. at Mead Stream), and during the K/X event $(0.4 \mathrm{~cm} / \mathrm{k}$.yr. at site $1262 ; 4.5 \mathrm{~cm} / \mathrm{k}$.yr. at Mead Stream). The patterns observed by Nicolo et al. (2007) extend across at least 6 m.yr. of the early Paleogene.

Carbonate dissolution in the deep sea and terrigenous dilution along continental margins likely characterizes the EECO (fig. 7), although this is complicated. First, as noted previously, the EECO lacks a formal definition for correlation purposes, although it has been known for awhile that 1-2 m.yr. of the early Eocene were remarkably warm across the globe, especially at high latitudes (Sluijs et al. 2008; Zachos et al. 2008; McInerney and Wing 2011), including around New Zealand (Bijl et al. 2009; Hollis et al. 2009; Sluijs et al. 2011). Second, the coupling between temperature and carbon cycling is skewed in the time domain, such that the 


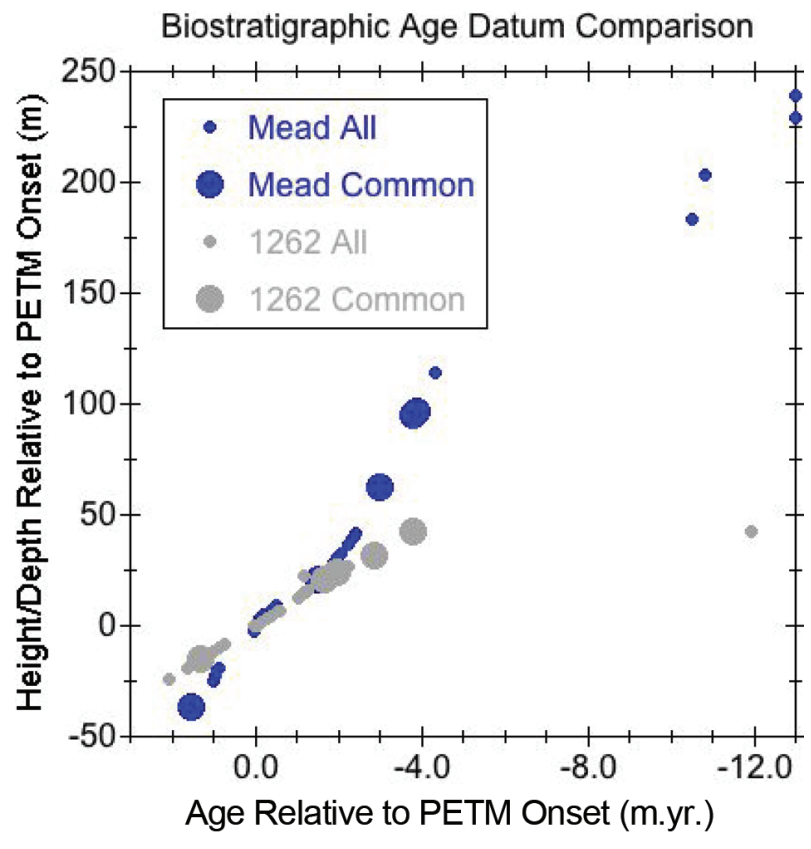

Figure 7. Radiolarian, foraminiferal, and nannofossil biostratigraphic age datum comparison between site 1262 (Zachos et al. 2004; Agnini et al. 2007) and Mead Stream (Hollis et al. 2005b). Ages and heights/depths are plotted relative to the onset of the Paleocene-Eocene thermal maximum (PETM). Common biostratigraphic datums to both sites are shown as large circles, while those found at only one site are shown as small circles. Note the large difference in compacted linear sedimentation rates across the PETM and throughout the Early Eocene climatic optimum.

minimum in long-term $\delta^{13} \mathrm{C}$ records (i.e., very likely the $\mathrm{K} / \mathrm{X}$ event) occurred near the initiation of EECO. Nonetheless, the approximate time interval of EECO at sites 1262 and 577 spans 10 and $4 \mathrm{~m}$, respectively. By contrast, at Mead Stream, this interval spans at least $46 \mathrm{~m}$ (fig. 2), and the overall compacted sedimentation rate $(3.9 \mathrm{~cm} / \mathrm{k}$.yr. $)$ is almost double that for sediment deposited between 57 and $53 \mathrm{Ma}(2.0 \mathrm{~cm} / \mathrm{k} . y \mathrm{r}$.$) , which includes ele-$ vated sediment accumulation across the PETM, the $\mathrm{H}$ and I events. Lower Marl at Mead Stream appears to represent an expanded lithological expression of EECO (fig. 2).

The thickness of marl-rich units at Mead Stream does not scale directly with the size of corresponding CIEs. In particular, the magnitudes of CIEs $(0.2 \%$ - $0.6 \%$ o $)$ during EECO were less pronounced than during the PETM $(2.5 \%)$ or ETM-2 $(1.0 \%)$, but the marl units are more common during EECO. There are two general possibilities involving changes in "background" conditions. First, there was an overall warming from ca. 58 to $51 \mathrm{Ma}(\mathrm{Za}$ - chos et al. 2008; Bijl et al. 2009; Westerhold et al. 2011). Thus, if the supply of terrigenous sediment relates to absolute temperature, the thicknesses of marl units should increase up the section, as observed. Second, there was an overall drop in $\delta^{13} \mathrm{C}$ from 58.0 to $52.5 \mathrm{Ma}$ (Zachos et al. 2001, 2008, 2010; Cramer et al. 2009). This may represent a long-term net transfer of ${ }^{13} \mathrm{C}$-depleted $\mathrm{CO}_{2}$ from a "capacitor" to the exogenic carbon cycle (Dickens 2011). As a result, for a given environmental perturbation and short-term input of ${ }^{13} \mathrm{C}$-depleted $\mathrm{CO}_{2}$, the magnitude of the CIE would have been damped (Dickens 2011).

The local context is also worth considering. The entire margin of New Zealand subsided and deepened throughout the Paleogene, leading to widespread carbonate deposition in the Eocene and Oligocene (King et al. 1999). Across Clarence River Valley sequences, thicknesses of all lithological units generally increase with paleodepth (Reay 1993), being thickest near the depocenter as represented by the Mead Stream section. This is exemplified by Dee Marl, the unit that marks the PETM, which thins toward the paleo-coast, being $2.4 \mathrm{~m}$ at Mead Stream (Hollis et al. 2005a), $1.0 \mathrm{~m}$ at Dee Stream (Hancock et al. 2003), and $0.8 \mathrm{~m}$ at Muzzle Stream (Hollis et al. 2005b). Thus, a progressive increase in paleodepth over the 2-3 m.yr. separating the PETM from the EECO may somehow translate to increased rates of terrigenous deposition on this margin. However, the thickness of Dee Marl relative to the thickness of surrounding Lower Limestone has an opposite relationship. The $1.0-$ and $0.8-\mathrm{m}$-thick intervals spanning the PETM at Dee Stream and Muzzle Stream represent much larger percentages of the total thickness of Lower Limestone in these sections (Hancock et al. 2003; Hollis et al. 2005b).

An Earth Systems Perspective. The general trends in lithology and geochemistry at Mead Stream have been shown to represent Amuri Limestone at multiple sites in northeastern South Island (Reay 1993; Hancock et al. 2003; Hollis et al. 2005a, 2005b). Thus, they likely reflect regional responses to past changes in environmental conditions.

Regardless of source, rapid and massive injections of ${ }^{13} \mathrm{C}$-depleted $\mathrm{CO}_{2}$ should cause negative CIEs and carbonate dissolution in deep-sea sediment, the latter expressed by rises in the lysocline and calcite compensation depth (CCD; Dickens et al. 1997; Zachos et al. 2005; Leon-Rodriguez and Dickens 2010; Stap et al. 2010). The associated abrupt warming might also give a predictable response to sedimentation along continental margins. Climate model simulations (Murphy et al. 
2004; Held and Soden 2006; Meehl et al. 2007a, $2007 b$ ) and river discharge data (e.g., Peterson et al. 2002) consistently indicate that, in a warmer world, the hydrological cycle accelerates, whereby the atmosphere carries more water from low to high latitudes. These models further suggest that precipitation becomes more seasonal. The overall combination for many midlatitude regions, such as the location of New Zealand through the Cenozoic, is greater precipitation but over a shorter time of the year (Meehl et al. 2007a, 2007b). This should lead to decreased vegetation, intensified chemical weathering, greater physical erosion, and enhanced discharge of terrigenous material from rivers to continental margins (Ludwig and Probst 1998; Schmitz and Pujalte 2003; Meehl et al. 2007a, 2007b; Schmitz and Pujalte 2007).

The remarkable correlation of late Paleoceneearly Eocene CIEs and clay-rich units at site 1262 and Mead Stream suggests that, for over $\sim 6$ m.yr., there was a series of short-term climate perturbations, each characterized by a systemic response in a different environment. At site 1262, strata deposited during these perturbations are intervals of carbonate dissolution; at Mead Stream, they are intervals of terrigenous dilution. Collectively, they probably reflect a link in Earth systems involving ocean acidification and enhanced seasonal precipitation (fig. 8). This suspected link is found in climate model simulations for geologically brief times of warming and massive carbon input, such as might occur in the coming millennia (Meehl et al. 2007a, 2007b; Allan and Soden 2008).

Quantitative coupling of parameters for carbonate dissolution in the deep ocean and siliciclastic flux on continental margins across each hyperthermal is tantalizing but complicated, as both are likely influenced by differences in boundary conditions before and during the events. In particular, consider such coupling of records on the millionyear timescale from the late Paleocene through EECO. Between 58 and $51 \mathrm{Ma}$, benthic foraminifera carbon isotope records show an $\sim 2 \%$ decrease in $\delta^{13} \mathrm{C}$ (Zachos et al. 2001; Cramer et al. 2009), and deep-sea sediment records suggest an overall deepening of the CCD (Hancock et al. 2007; Leon-Rodriguez and Dickens 2010). Presumably, the two observations collectively indicate a significant increase in net fluxes of ${ }^{13} \mathrm{C}$-depleted carbon to the ocean and atmosphere, but at a sufficiently slow rate so that carbon inputs were buffered by alkalinity supply to the ocean (Hancock et al. 2007; Leon-Rodriguez and Dickens 2010). The succession of hyperthermals, and their environmental manifestations, very likely occurred over a long time interval when surface temperatures generally rose (Zachos et al. 2008; Bijl et al. 2009; Westerhold et al. 2011) and the exogenic carbon cycle generally gained mass.

Benthic foraminifera carbon isotope records show a $\sim 1 \%$ o increase in $\delta^{13} \mathrm{C}$ from 52 to $49 \mathrm{Ma}$ (Zachos et al. 2001). Multiple deep-sea sediment sequences also suggest a major rise in the CCD over this time interval (Hancock et al. 2007; Leon-Rodriguez and Dickens 2010). The simplest interpretation is a pronounced decrease in net long-term fluxes of ${ }^{13} \mathrm{C}$-depleted carbon to the ocean and atmosphere (Hancock et al. 2007; Zachos et al. 2008; Leon-Rodriguez and Dickens 2010). Benthic foraminifera oxygen isotope records also show an increase in $\delta^{18} \mathrm{O}$ following EECO, which heralds the start of long-term Cenozoic cooling, at least at high latitudes (Zachos et al. 2001; Bijl et al. 2009; Cramer et al. 2009; Hollis et al. 2009). However, global cooling begins about $51 \mathrm{Ma}$ (Bijl et al. 2009; Hollis et al. 2009; Cramer et al. 2011), or about 1 m.yr. after the presumed change in net carbon fluxes. Major carbonate dissolution in the deep sea, therefore, may have coincided with high fluxes of terrigenous sediment during part of the EECO. This would further explain why the Mead Stream record is so expanded across the EECO compared to that in deep-sea sections (fig. 2).

Lower Marl lies beneath Upper Limestone. It is possible that the transition between these units marks the end of the EECO (fig. 2) and the waning of terrigenous fluxes during the start of Cenozoic cooling. Interestingly, at Mead Stream and elsewhere in eastern Marlborough, Upper Limestone is overlain in turn by Upper Marl, the top unit of Amuri Limestone (Reay 1993; Strong et al. 1995). One might speculate that, like the EECO, this unit represents another interval of anomalously high temperatures and elevated terrigenous discharge to the ancient New Zealand continental margin. Upper Marl may be the lithological expression of the Middle Eocene Climatic Optimum (MECO), which began $\sim 41.5 \mathrm{Ma}$ and lasted for about $0.6 \mathrm{~m}$.yr. (Bohaty and Zachos 2003). However, appropriate records to evaluate this idea have not been generated yet.

\section{Summary and Conclusions}

Mead Stream exposes a thick and continuous section of sedimentary rocks originally deposited on the continental slope of New Zealand from the late Cretaceous to middle Eocene (Strong et al. 1995; Hollis et al. 2005a). The continuous section rep- 

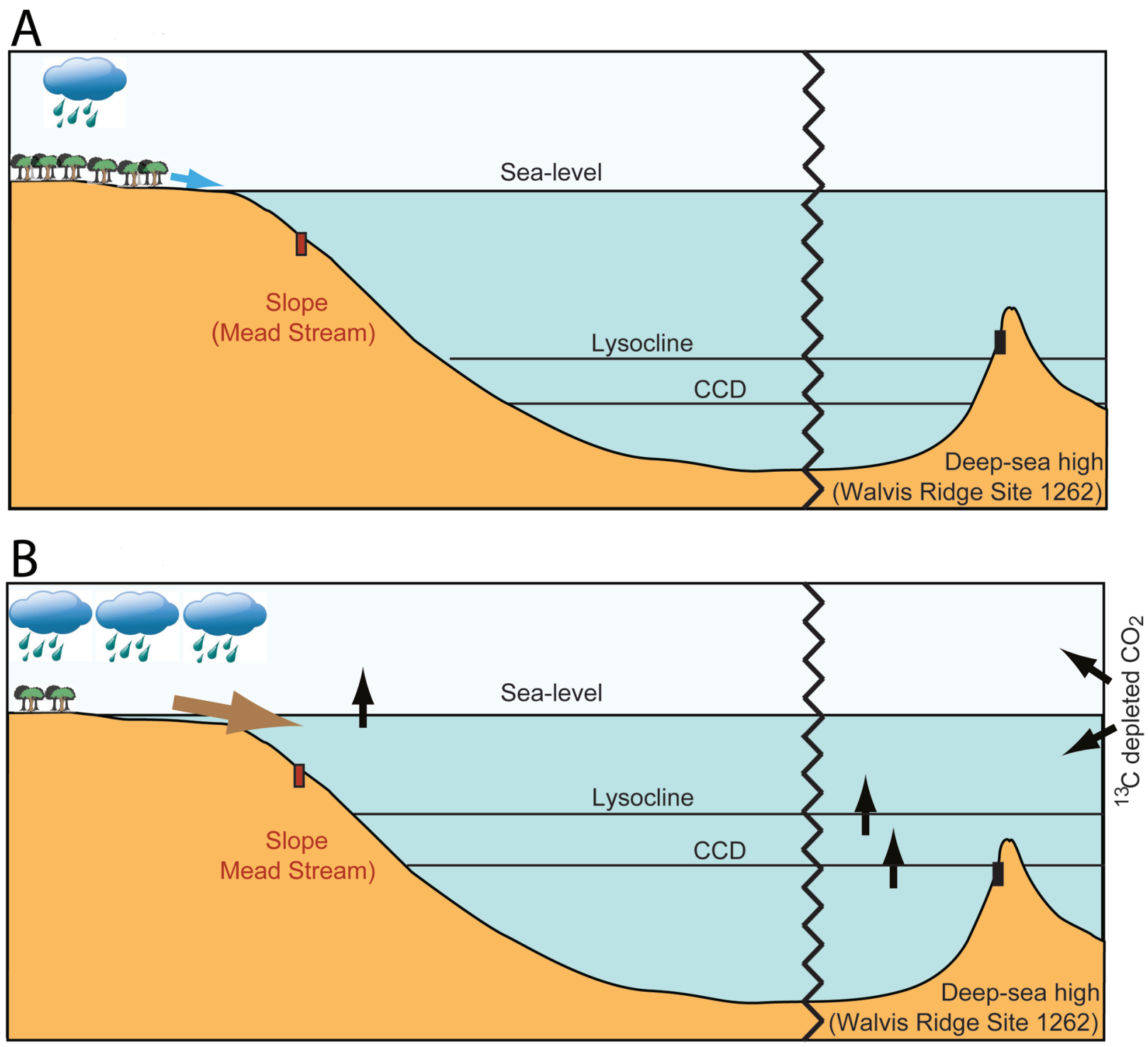

Figure 8. Cartoon view to explain the similar lithological and geochemical patterns observed in the deep sea and on continental margins during the early Eocene. During times of high Earth surface temperature and massive carbon input (e.g., hyperthermals), the release of ${ }^{13} \mathrm{C}$-depleted $\mathrm{CO}_{2}$ caused negative $\delta^{13} \mathrm{C}$ excursions and shoaled the lysocline and carbonate compensation depth (CCD) impacting deep-sea settings (e.g., site 1262). Contemporaneously, an enhanced hydrological cycle occurred, which caused elevated annual precipitation but over a shorter season. This reduced vegetation and led to greater terrigenous sediment fluxes to continental slope settings (e.g., Mead Stream).

resents regional sediment accumulation (Hollis et al. 2005) during a time interval marked by major changes in climate and carbon cycling (Zachos et al. 2008). This study extends previous records of lithology, carbonate content, and bulk carbonate $\delta^{13} \mathrm{C}$ at Mead Stream (Hollis et al. 2005a; Nicolo et al. 2007), so that relationships between the rock record and changing environmental conditions can be understood through much of the EECO.

The previously well-documented Lower Limestone is overlain by Lower Marl, which represents the EECO $(\sim 53-51 \mathrm{Ma})$, and is comprised of interbedded limestone and marl. Within this unit, there are 10 intervals with more prevalent marl beds and generally lower carbonate content (figs. 2, 3). Bulk carbonate $\delta^{13} \mathrm{C}$ analyses across these intervals show that they broadly correspond to CIEs (fig. 5). Moreover, the most prominent marl sequence and CIE marks the $\mathrm{K} / \mathrm{X}$ event. It is possible, if not likely, that the EECO was characterized by a series of short-term negative CIEs.

The negative CIEs very likely represent abrupt 
releases of ${ }^{13} \mathrm{C}$-depleted $\mathrm{CO}_{2}$ into the ocean and atmosphere (Dickens et al. 1995, 1997; Thomas and Shackleton 1996; Lourens et al. 2005; Zachos et al. 2005; Zeebe et al. 2009; Leon-Rodriguez and Dickens 2010; Dickens 2011). Marls at Mead Stream represent short-term increases in terrigenous sedimentation and carbonate dilution. Considering that several of the CIEs have been linked to warmer Earth surface temperatures (Sluijs et al. 2007; Zachos et al. 2010; McInerney and Wing 2011; Westerhold et al. 2011), the best explanation for the marls is that they reflect an accelerated hydrological cycle with enhanced seasonality (Giusberti et al. 2007; Nicolo et al. 2007; John et al. 2008). This would lead to greater chemical weathering and physical erosion on continents and elevated siliciclastic fluxes to the marine realm, especially at higher latitudes. The EECO, as expressed by Lower Marl, is greatly expanded at Mead Stream. It is likely this time was characterized by a series of warm events with pulses of greater terrigenous discharge to the margin.

\section{A C K N O W L E D G M E N T S}

We thank R. Murray and S. Murray for field access, logistical support, and hospitality. We also thank G. Snyder for overseeing and managing sample preparation in the geochemistry laboratory at Rice University and D. Andreasen for helping with stable isotope analyses at the University of California, Santa Cruz. T. Westerhold, E. Thomas, and an anonymous reviewer provided constructive comments that greatly improved the quality of the manuscript. Funding for this work principally came from Rice University through a grant to G. R. Dickens. C. J. Hollis and J. S. Crampton acknowledge funding from the New Zealand Government (contract C05X0701). Funding for A. Sluijs was provided by the European Research Council under the European Community's Seventh Framework Program through European Research Council Starting Grant 259627. A. Sluijs thanks the Royal Netherlands Academy of Arts and Sciences for a Visiting Professors Programme Grant to G. R. Dickens.

\section{REFERE N C E S C I T E D}

Agnini, C.; Fornaciari, E.; Raffi, I.; Rio, D.; Rohl, U.; and Westerhold, T. 2007. High-resolution nannofossil biochronology of middle Paleocene to early Eocene at ODP site 1262: implications for calcareous nannoplankton evolution. Mar. Micropaleontol. 64:215-248.

Agnini, C.; Macrì, P.; Backman, J.; Brinkhuis, H.; Fornaciari, E.; Giusberti, L.; Luciani, V.; Rio, D.; Sluijs, A.; and Speranza, F. 2009. An early Eocene carbon cycle perturbation at $\sim 52.5 \mathrm{Ma}$ in the southern Alps: chronology and biotic response. Paleoceanography 24: PA2209, doi:10.1029/2008PA001649.

Allan, R. P., and Soden, B. J. 2008. Atmospheric warming and the amplification of precipitation extremes. Science 321:1481-1484.

Berggren, W. A.; Kent, D. V.; Swisher, C. C., III; and Aubry, M.-P. 1995. A revised Cenozoic geochronology and chronostratigraphy. In Kent, D. V.; Aubry, M.-P.; and Hardenbol, J., eds. Geochronology time scales and global stratigraphic correlation. Society for Sedimentary Geology, Tulsa, OK, Special Publication 54:129212.

Bijl, P. K.; Schouten, S.; Sluijs, A.; Reichart, G.-J.; Zachos, J. C.; and Brinkhuis, H. 2009. Early Palaeogene temperature evolution of the southwest Pacific Ocean. Nature 461:776-779, doi:10.1038/nature08399.

Bohaty, S. M., and Zachos, J. C. 2003. Significant Southern Ocean warming event in the late middle Eocene. Geology 31:1017-1020.

Christensen, J. H.; Hewitson, B.; Busuioc, A.; Chen, A.; Gao, X.; Held, I.; Jones, R.; et al. 2007. Regional climate projects. In Solomon, S.; Qin, D.; Manning, M.; Chen, Z.; Marquis, M.; Averyt, K. B.; Tignor, M.; and
Miller, H. L., eds. Climate change 2007: the physical science basis. Contribution of Working Group I to the Fourth Assessment Report of the Intergovernmental Panel on Climate Change. Cambridge, Cambridge University Press.

Cramer, B. S.; Miller, K. G.; Barrett, P. J.; and Wright, J. D. 2011. Late Cretaceous-Neogene trends in deep ocean temperature and continental ice volume: reconciling records of benthic foraminiferal geochemistry $\left(\delta^{18} \mathrm{O}\right.$ and $\left.\mathrm{Mg} / \mathrm{Ca}\right)$ with sea level history. J. Geophys. Res. 116:C12023, doi:10.1029/2011JC007255.

Cramer, B. S.; Toggweiler, J. R.; Wright, J. D.; Katz, M. E.; and Miller, K. G. 2009. Ocean overturning since the late Cretaceous: inferences from a new benthic foraminiferal isotope compilation. Paleoceanography 24:PA4216, doi:10.1029/2008PA001683.

Cramer, B. S.; Wright, J. D.; Kent, D. V.; and Aubry, M.-P. 2003. Orbital climate forcing of $\delta^{13} \mathrm{C}$ excursion in the late Paleocene-early Eocene (chrons C24n-C25n). Paleoceanography 18:1097, doi:10.1029/2003PA000909.

Crampton, J.; Laird, M.; Nicol, A.; Townsend, D.; and Van Dissen, R. 2003. Palinspastic reconstructions of southeastern Marlborough, New Zealand, for late Cretaceous to Eocene times. N. Z. J. Geol. Geophys. 46: 153-175.

Crouch, E. M.; Dickens, G. R.; Brinkhuis, H.; Aubry, M.P.; Hollis, C. J.; Rogers, K. M.; and Visscher, H. 2003. The Apectodinium acme and terrestrial discharge during the Paleocene-Eocene thermal maximum: new palynological, geochemical and calcareous nannoplankton observations at Tawanui, New Zealand. Pa- 
laeogeogr. Palaeoclimatol. Palaeoecol. 194:387-403, doi:10.1016/S0031-0182/03)00334-1.

Dickens, G. R. 2011. Down the rabbit hole: toward appropriate discussion of methane release from gas hydrate systems during the Paleocene-Eocene thermal maximum and other past hyperthermal events. Clim. Past 7:831-846.

Dickens, G. R.; Castillo, M. M.; and Walker, J. C. G. 1997. A blast of gas in the latest Paleocene: simulating firstorder effects of massive dissociation of oceanic methane hydrate. Geology 25:259-262.

Dickens, G. R.; O'Neil, J. R.; Rea, D. K.; and Owen, R. M. 1995. Dissociation of oceanic methane hydrate as a cause of the carbon-isotope excursion at the end of the Paleocene. Paleoceanography 10:965-971.

Dunn, D. A. 1980. Revised techniques for quantitative calcium carbonate analysis using the "karbonatbombe," and comparisons to other quantitative carbonate analysis methods. J. Sediment. Res. 50:631637.

Galeotti, S.; Krishnan, S.; Pagani, M.; Lanci, L.; Gaudio, A.; Zachos, J. C.; Monechi, S.; Morelli, G.; and Lourens, L. 2010. Orbital chronology of early Eocene hyperthermals from the Contessa road section, central Italy. Earth Planet. Sci. Lett. 290:192-200.

Giusberti, L.; Rio, D.; Agnini, C.; Backman, J.; Fornaciari, E.; Tateo, F.; and Oddone, M. 2007. Mode and tempo of the Paleocene-Eocene thermal maximum in an expanded section from the Venetian pre-Alps. Geol. Soc. Am. Bull. 119:391-412, doi:10.1130/B25994.1.

Hancock, H. J. L.; Dickens, G. R.; Strong, C. P.; Hollis, C. J.; and Field, B. D. 2003. Foraminiferal and carbon isotope stratigraphy through the Paleocene-Eocene transition at Dee Stream, Marlborough, New Zealand. N. Z. J. Geol Geophys. 46:1-19.

Hancock, H. J. L.; Dickens, G. R.; Thomas, E.; and Blake, K. L. 2007. Reappraisal of early Paleogene CCD curves: foraminiferal assemblages and stable carbon isotopes across the carbonate facies of Perth Abyssal Plain. Intl. J. Earth Sci. 96:925-946.

Held, I. M., and Soden, B. J. 2006. Robust responses of the hydrological cycle to global warming. J. Clim. 19: 5686-5699.

Hilgen, F. J.; Kuiper, K. F.; and Lourens, L. J. 2010. Evaluation of the astronomical time scale for the Paleocene and earliest Eocene. Earth Planet. Sci. Lett. 300: 139-151.

Hollis, C. J. 2002. Biostratigraphy and paleoceanographic significance of Paleocene radiolarians from offshore eastern New Zealand. Mar. Micropaleontol. 46:265316.

Hollis, C. J.; Dickens, G. R.; Field, B. D.; Jones, C. M.; and Strong, C. P. 2005a. The Paleocene-Eocene transition at Mead Stream, New Zealand: a southern Pacific record of early Cenozoic global change. Palaeogeogr. Palaeoclimatol. Palaeoecol. 215:313-343, doi: 10.1016/j.palaeo.2004.09.011.

Hollis, C. J.; Field, B. D.; Jones, C. M.; Strong, C. P.; Wilson, G. J.; and Dickens, G. R. 2005b. Biostratigraphy and carbon isotope stratigraphy of uppermost
Cretaceous-lower Cenozoic in middle Clarence Valley, New Zealand. J. R. Soc. N. Z. 35:345-383.

Hollis, C. J.; Handley, L.; Crouch, E. M.; Morgans, H. E. G.; Baker, J. A.; Creech, J.; Collins, K. S.; et al. 2009. Tropical sea temperatures in the high-latitude south Pacific during the Eocene. Geology 37:99-102.

Hollis, C. J.; Rodgers, K. A.; Strong, C. P.; Field, B. D.; and Rogers, K. M. 2003. Paleoenvironmental changes across the Cretaceous/Tertiary boundary in the northern Clarence Valley, southeastern Marlborough, New Zealand. N. Z. J. Geol. Geophys. 46:209-234.

Höntzsch, S.; Scheibner, C.; Guasti, E.; Kuss, J.; Marzouk, A. M.; and Rasser, M. W. 2011. Increasing restriction of the Egyptian shelf during the early Eocene? new insights from a southern Tethyan carbonate platform. Palaeogeogr. Palaeoclimatol. Palaeoecol. 302:349-366.

John, C. M.; Bohaty, S. M.; Zachos, J. C.; Sluijs, A.; Gibbs, S.; Brinkhuis, H.; and Bralower, T. J. 2008. North American continental margin records of the Paleocene-Eocene thermal maximum: implications for global carbon and hydrological cycling. Paleoceanography 23:PA2217, doi:10.1029/2007PA001465.

King, P. R.; Naish, T. R.; Browne, G. H.; Field, B. D.; and Edbrooke, S. W. 1999. Cretaceous to Recent sedimentary patterns in New Zealand. Institute of Geological and Nuclear Sciences folio series 1. Lower Hutt, NZ, Institute of Geological and Nuclear Sciences.

Leon-Rodriguez, L., and Dickens, G. R. 2010. Constraints on ocean acidification associated with rapid and massive carbon injections: the early Paleogene record at ocean drilling program site 1215 , equatorial Pacific Ocean. Palaeogeogr. Palaeoclimatol, Palaeoecol. 298: 409-420.

Lourens, L. J.; Sluijs, A.; Kroon, D.; Zachos, J. C.; Thomas, E.; Rohl, U.; Bowles, J.; and Raffi, I. 2005. Astronomical pacing of late Palaeocene to early Eocene global warming events. Nature 435:1083-1087, doi:10.1038/ nature 03814.

Ludwig, W., and Probst, J.-L. 1998. River sediment discharge to the oceans: present-day controls and global budgets. Am. J. Sci. 298:265-295.

McInerney, F. A., and Wing, S. L. 2011. The PaleoceneEocene thermal maximum: a perturbation of carbon cycle, climate, and biosphere with implications for the future. Annu. Rev. Earth Planet. Sci. 39:489-516.

Meehl, G. A.; Covey, C.; Delworth, T.; Latif, M.; McAvaney, B.; Mitchell, J. F. B.; Stouffer, R. J.; and Taylor, K. E. 2007a. The WCRP CMIP3 multimodel dataset: a new era in climatic change research. Bull. Am. Meteorol. Soc. 88:1383-1394.

Meehl, G. A.; Stocker, T. F.; Collins, W. D.; Friedlingstein, P.; Gaye, A. T.; Gregory, J. M.; Kitoh, A.; et al. $2007 b$. Global climate projections. In Solomon, S.; Qin, D.; Manning, M.; Chen, Z.; Marquis, M.; Averyt, K. B.; Tignor, M.; et al., eds. Climate change 2007: the physical science basis. Contibution of Working Group I to the Fourth Assessment Report of the Intergovernmental Panel on Climate Change. Cambridge, Cambridge University Press.

Murphy, B. H.; Farley, K. A.; and Zachos, J. C. 2010. An 
extraterrestrial ${ }^{3} \mathrm{He}$-based timescale for the PaleoceneEocene thermal maximum (PETM) from Walvis Ridge, IODP site 1266. Geochim. Cosmochim. Acta 74: 5098-5108.

Murphy, J. M.; Sexton, D. M. H.; Barnett, D. N.; Jones, G. S.; Webb, M. J.; Collins, M.; and Stainforth, D. A. 2004. Quantification of modeling uncertainties in a large ensemble of climate change simulations. Nature 430:768-772.

Muttoni, G., and Kent, D. V. 2007. Widespread formation of cherts during the early Eocene climate optimum. Palaeogeogr. Palaeoclimatol. Palaeoecol. 253:348-362.

Nicolo, M. J.; Dickens, G. R.; and Hollis, C. J. 2010. South Pacific intermediate water oxygen depletion at the onset of the Paleocene-Eocene thermal maximum as depicted in New Zealand margin sections. Paleoceanography 25:PA4210, doi:10.1029/2009PA001904.

Nicolo, M. J.; Dickens, G. R.; Hollis, C. J.; and Zachos, J. C. 2007. Multiple early Eocene hyperthermals: their sedimentary expression on the New Zealand continental margin and in the deep sea. Geology 35:699702, doi:10.1130/G23648A.1.

Peterson, B. J.; Holmes, R. M.; McClelland, J. W.; Vörösmarty, C. J.; Lammers, R. B.; Shiklomanov, A. L.; Shiklomanov, I. A.; and Rahmstorf, S. 2002. Increasing river discharge to the Arctic Ocean. Science 298:21712173.

Randall, D. A.; Wood, R. A.; Bony, S.; Colman, R.; Fichefet, T.; Fyfe, J.; Kattsov, V.; et al. 2007. Climate models and their evaluation. In Solomon, S.; Qin, D., Manning, M.; Chen, Z.; Marquis, M.; Averyt, K. B.; Tignor, M.; and Miller, H. L., eds. Climate change 2007: the physical science basis. Contribution of Working Group I to the Fourth Assessment Report of the Intergovernmental Panel on Climate Change. Cambridge, Cambridge University Press.

Reay, M. B. 1993. Geology of the middle part of the Clarence Valley. Inst. Geol. Nucl. Sci. Geol. Map 10:1144.

Robert, C. 2004. Cenozoic environments in the Tasmanian area of the Southern Ocean (ODP leg 189): inferences from bulk and clay mineralogy. In Exon, N.; Kennett, J. P.; and Malone, M., eds. The Cenozoic Southern Ocean: tectonics, sedimentation and climate change between Australia and Antarctica. Geophys. Monogr. 151. Washington, DC, Am. Geophys. Union, p. 43-62.

Röhl, U.; Westerhold, T.; Monechi, S.; Thomas, E.; Zachos, J. C.; and Donner, B. 2005. The third and final early Eocene thermal maximum: characteristics, timing, and mechanisms of the " $\mathrm{X}$ " event. Paper 117-2. Geo. Soc. Am. Abstr. Program 37:264.

Schmitz, B., and Pujalte, V. 2003. Sea-level, humidity, and land-erosion records across the initial Eocene thermal maximum from a continental-marine transect in northern Spain. Geology 31:689-692.

Schmitz, B.; Pujalte, V.; and Nunez-Betelu, K. 2001. Climate and sea-level perturbations during the initial Eocene thermal maximum: evidence from siliciclastic units in the Basque basin (Ermua, Zumaia and Tra- bakua Pass), northern Spain. Palaeogeogr. Palaeoclimatol. Palaeoecol. 165:299-320, doi:10.1016/S00310182(00)00167-X.

- 2007. Abrupt increase in seasonal extreme precipitation at the Paleocene-Eocene boundary. Geology 35:215-218

Sexton, P. F.; Norris, R. D.; Wilson, P. A.; Palike, H.; Westerhold, T.; Rohl, U.; Bolton, C. T.; and Gibbs, S. 2011. Eocene global warming events driven by ventilation of oceanic dissolved organic carbon. Nature 471:349-353.

Shackleton, N. J., and Hall, M. A. 1984. Carbon isotope data from leg 74 sediments. In Blakeslee, J., and $\mathrm{M}$. Lee, eds. Vol. 74. Cape Town to Walvis Bay. Initial Reports of the Deep Sea Drilling Project 74:613-619.

- 1990. Carbon isotope stratigraphy of bulk sediments, ODP sites 689 and 690, Maud Rise, Antarctica. In Barker, P. F., and Kennett, J. P., eds. Proceedings of the Ocean Drilling Program, Scientific Results, leg 113, 113:985-989.

Shackleton, N. J.; Hall, M. A.; and Bleil, U. 1985. Carbon isotope stratigraphy, site 577 . In K. L. Turner, ed. Initial Reports of the Deep Sea Drilling Project 86:503511.

Sluijs, A.; Bijl, P. K.; Schouten, S.; Röhl, U.; Reichert, G.J.; and Brinkhuis, H. 2011. Southern Ocean warming, sea level and hydrological change during the Paleocene-Eocene thermal maximum. Clim. Past 7:47-61.

Sluijs, A.; Bowen, G.; Brinkhuis, H.; Lourens, L. J.; and Thomas, E. 2007. The Palaeocene-Eocene thermal maximum super greenhouse: biotic and geochemical signatures, age models and mechanisms of global change. In Williams, M.; Haywood, A. M.; Gregory, J.; and Schmidt, D. N., eds. Deep-time perspectives on climate change: marrying the signal from computer models and biological proxies. Special publication. London, Micropaleontological Society, p. 323-349.

Sluijs, A.; Röhl, U.; Schouten, S.; Brumsack, H.-J.; Sangiorgi, F.; Sinninghe Damsté, J. S.; and Brinkhuis, H. 2008. Arctic late Paleocene-early Eocene paleoenvironments with special emphasis on the PaleoceneEocene thermal maximum (Lomonosov Ridge, integrated Ocean Drilling Program expedition 302). Paleoceanography 23:PA1S11, doi:10.1029/ 2007PA001495.

Stap, L.; Lourens, L. J.; Thomas, E.; Sluijs, A.; Bohaty, S.; and Zachos, J. C. 2010. High-resolution deep-sea carbon and oxygen isotope records of Eocene thermal maximum 2 and H2. Geology 38:607-610.

Stap, L.; Sluijs, A.; Thomas, E.; and Lourens, L. 2009. Patterns and magnitude of deep sea carbonate dissolution during Eocene thermal maximum 2 and $\mathrm{H} 2$, Walvis Ridge, southeastern Atlantic Ocean. Paleoceanography 24:PA1211, doi:10.1029/2008PA001655.

Strong, C. P.; Hollis, C. J.; and Wilson, G. J. 1995. Foraminiferal, radiolarian, and dinoflagellate biostratigraphy of Late Cretaceous to middle Eocene pelagic sediments (Muzzle group), Mead Stream, Marlborough, New Zealand. N. Z. J. Geol. Geophys. 38:171209. 
Thomas, E., and Shackleton, N. J. 1996. The PaleoceneEocene benthic foraminiferal extinction and stable isotope anomalies. In Knox, R. W., ed. Correlation of the early Palaeogene in northwest Europe. Geol. Soc. Lond. Spec. Publ. 101:401-441.

Thomas, E., and Zachos, J. C. 2000. Was the late Paleocene thermal maximum a unique event? GFF 122: 169-170.

Westerhold, T., and Röhl, U. 2009. High resolution cyclostratigraphy of the early Eocene: new insights into the origin of the Cenozoic cooling trend. Clim. Past 5:309-327.

Westerhold, T.; Röhl, U.; Donner, B.; McCarren, H. K.; and Zachos, J. C. 2011. A complete high-resolution Paleocene benthic stable isotope record for the central pacific (ODP Site 1209). Paleoceanography 26:PP2216, doi:10.1029/2010PA002092.

Westerhold, T.; Rohl, U.; McCarren, H. K.; and Zachos, J. C. 2009. Latest on the absolute age of the PaleoceneEocene thermal maximum (PETM): new insights from exact stratigraphic position of key ash layers +19 and -17. Earth Planet. Sci. Lett. 287:412-419.

Zachos, J. C.; Dickens, G. R.; and Zeebe, R. E. 2008. An early Cenozoic perspective on greenhouse warming and carbon-cycle dynamics. Nature 451:279-283.

Zachos, J. C.; Kroon, D.; Blum, P.; Bowles, J.; Gaillot, P.; Hasegawa, T.; Hathorne, E. C.; et al. 2004. Proceedings of the Ocean Drilling Program, initial reports, vol. 208, doi:10.2973/odp.proc.ir.208.2004.

Zachos, J. C.; McCarren, H.; Murphy, B.; Röhl, U., and Westerhold, T. 2010. Tempo and scale of late Paleocene and early Eocene carbon isotope cycles: implications for the origin of hyperthermals. Earth Planet. Sci. Lett. 299:242-249, doi:10.1016/j.eps1.2010.09 .004 .

Zachos, J. C.; Pagani, M.; Sloan, L.; Thomas, E.; and Billups, K. 2001. Trends, rhythms, and aberrations in global climate $65 \mathrm{Ma}$ to present. Science 292:686-693, doi:10.1126/science.1059412.

Zachos, J. C.; Röhl, U.; Schellenberg, S. A.; Sluijs, A.; Hodell, D. A.; Kelly, D. C.; Thomas, E.; et al. 2005. Rapid acidification of the ocean during the PaleoceneEocene thermal maximum. Science 308:1611-1615.

Zeebe, R. E.; Zachos, J. C.; and Dickens, G. R. 2009. Carbon dioxide forcing alone insufficient to explain Palaeocene-Eocene thermal maximum warming. Nature Geosci. 2:576-580. 